\title{
Genetics of Pheochromocytoma and Paraganglioma
}

\author{
Bernardo Dias Pereira ${ }^{1}$ • Henrique Vara Luiz² • Ana Gonçalves Ferreira² • \\ Jorge Portugal² \\ ${ }^{1}$ Serviço de Endocrinologia e Nutrição, Hospital Divino Espírito Santo de Ponta Delgada, \\ EPER, Ponta Delgada-Açores, Portugal; ${ }^{2}$ Serviço de Endocrinologia e Diabetes, Hospital \\ Garcia de Orta, EPE, Almada-Setúbal, Portugal
}

Author for correspondence: Bernardo Dias Pereira, MD, Serviço de Endocrinologia e Nutrição, piso 5, ala nascente, Hospital Divino Espírito Santo de Ponta Delgada, EPER, Av. D. Manuel I, 9500-370, Ponta Delgada_Açores,Portugal. Email: bern1981@gmail.com Doi: http://dx.doi.org/10.15586/paraganglioma.2019.ch1

\begin{abstract}
Pheochromocytomas and paragangliomas (PPGLs) are rare neuroendocrine tumors that often develop on a background of predisposing genetic mutations. With the continuous expansion of genetic landscape of PPGL, new tools of genetic screening have been developed for simultaneous parallel sequencing of multiple genes, at faster rates and lower costs. Yet, next-generation sequencing techniques are not available worldwide and demand expertise to circumvent technical limitations and interpret results of uncertain significance, and thus a sequential genetic analysis driven by the clinical phenotype remains advisable for a successful diagnosis, and to save costs. In this chapter, we focus on the clinical features of patients with PPGLs as a framework for an optimized sequential genetic screening. We also describe new syndromes and genes that are expanding the genetic etiology of PPGLs.
\end{abstract}

Keywords: Genetic testing; Multifocal tumors; Paraganglioma; Pheochromocytoma; SDH mutation

In: Paraganglioma: A Multidisciplinary Approach. Renato Mariani-Costantini (Editor), Codon Publications, Brisbane, Australia. ISBN: 978-0-9944381-7-1; Doi: http://dx.doi.org/10.15586/ paraganglioma.2019

Copyright: The Authors.

Licence: This open access article is licenced under Creative Commons Attribution 4.0 International (CC BY 4.0). https://creativecommons.org/licenses/by-nc/4.0/ 


\section{INTRODUCTION}

Pheochromocytomas (PHEO; MIM \#171300) and paragangliomas (PGLs; MIM \#168000) (pheochromocytomas and paragangliomas, PPGLs) are rare neuroendocrine tumors that arise in the adrenal medulla and in the ganglia of the sympathetic and parasympathetic nervous chains, respectively (1). The genetic landscape of PPGL has evolved over the years from the old "rule of tens" (10\%) for a genetic etiology to a prevalence of more than $40 \%$ of genetic mutations associated with these tumors $(2,3)$. Besides von Hippel-Lindau (VHL), rearranged during transfection (RET), and neurofibromatosis type 1 (NF1) genes, new germline mutations in the following genes that predispose to PPGLs have been identified: the succinate dehydrogenase subunits A/B/C/D/AF2 (SDHx), which cause paraganglioma syndrome types 1 to 5 (PGLl-5); Myc-associated protein X (MAX); transmembrane protein 127 (TMEM127), which causes the familial pheochromocytoma syndromes; hypoxia-inducible factor 2 alpha (HIF2A); fumarate hydratase (FH); prolyl hydroxylase types 1 and 2 (PHD1 and PHD2); kinesin family member 1B (KIF1B); and malate dehydrogenase 2 (MDH2) (4-17).

Considering the high costs of genetic screening and the large and increasing number of PPGL-associated genes, it is advised that clinicians follow a phenotypedriven algorithm when ordering genetic tests for patients with PPGL (Table 1). Additionally, it may be inadequate to screen for mutations in genes that have never been associated with a particular PPGL phenotype $(18,19)$. Syndromic presentations, multifocal tumors, metastatic disease, bilateral pheochromocytoma (bPHEO), and pediatric PPGLs are clinical features associated with a higher likelihood of a gene mutation, and these scenarios may entail the selection of a specific genetic screening (20-22). Furthermore, the type of catecholamine secretion by the PPGL, the pattern of immunostaining in pathology surveys, and results from functional nuclear imaging provide clues to prioritize the sequential genetic screening $(18,23-27)$.

\section{MOLECULAR PATHWAYS ASSOCIATED WITH PPGL}

The molecular pathways involved in the development of PPGL are classified according to three main clusters: a pseudohypoxic cluster (cluster 1: mutations in VHL, SDHx, HIF2A, PHD1/PHD2, FH, and MDH2), a cluster of kinase receptor signaling and protein translation pathways (cluster 2: mutations in RET, NF1, TMEM127, KIF1B, and MAX), and a cluster related to a Wnt-altered pathway (28-30). This last cluster includes only mutations at the somatic level that cause an aggressive form of sporadic pheochromocytoma (30).

In the pseudohypoxic cluster, there is a common denominator to all PPGLassociated mutations and their altered pathways, that is, overexpression of hypoxia-inducible factor type 2 alpha (HIF-2 $\alpha$ ), the predominant isoform of HIF- $\alpha$ in cells of neural crest origin $(31,32)$. Under hypoxia states, there is an overexpression of HIF-2 $\alpha$ which upregulates genes that are drivers of 


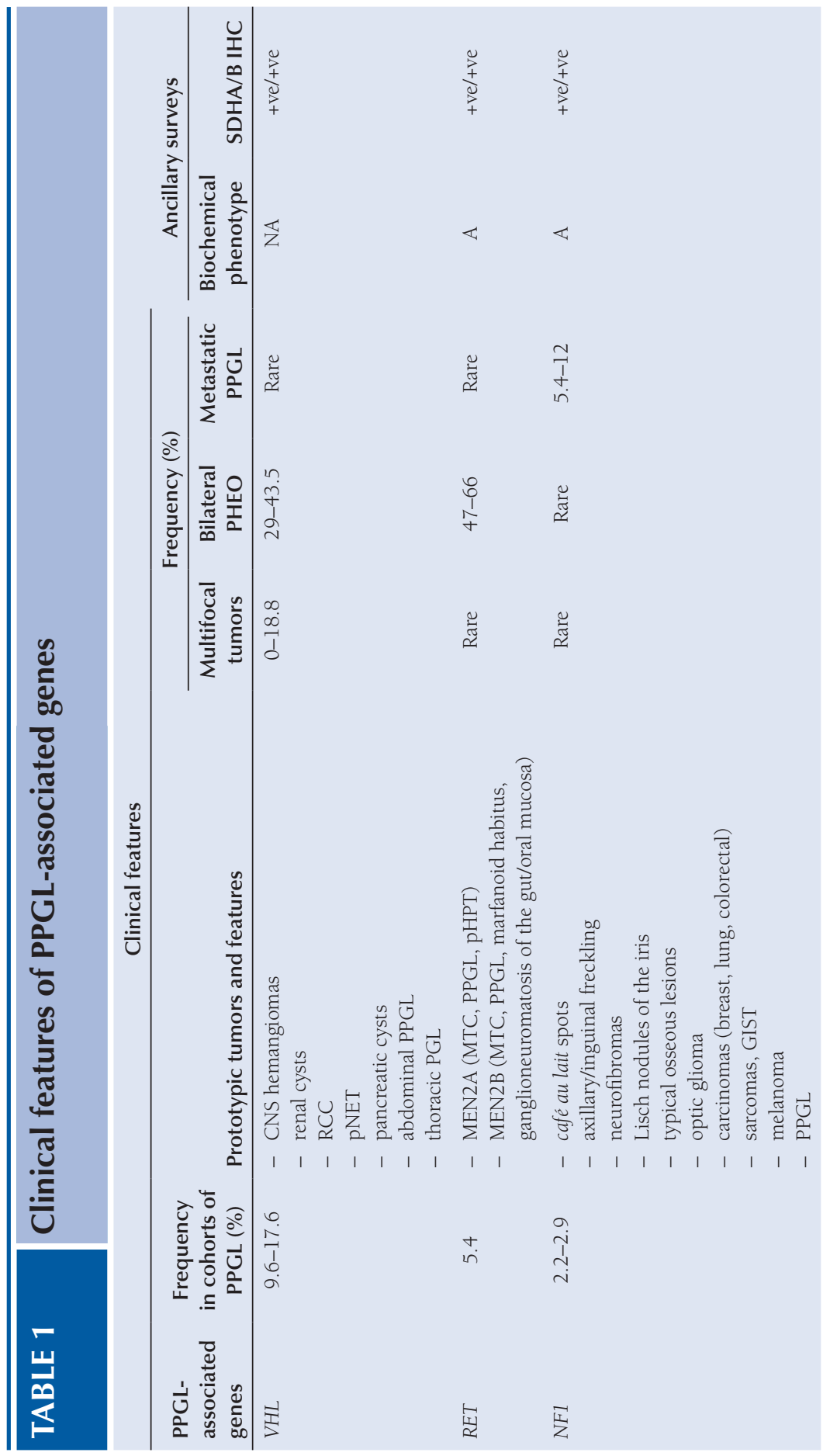




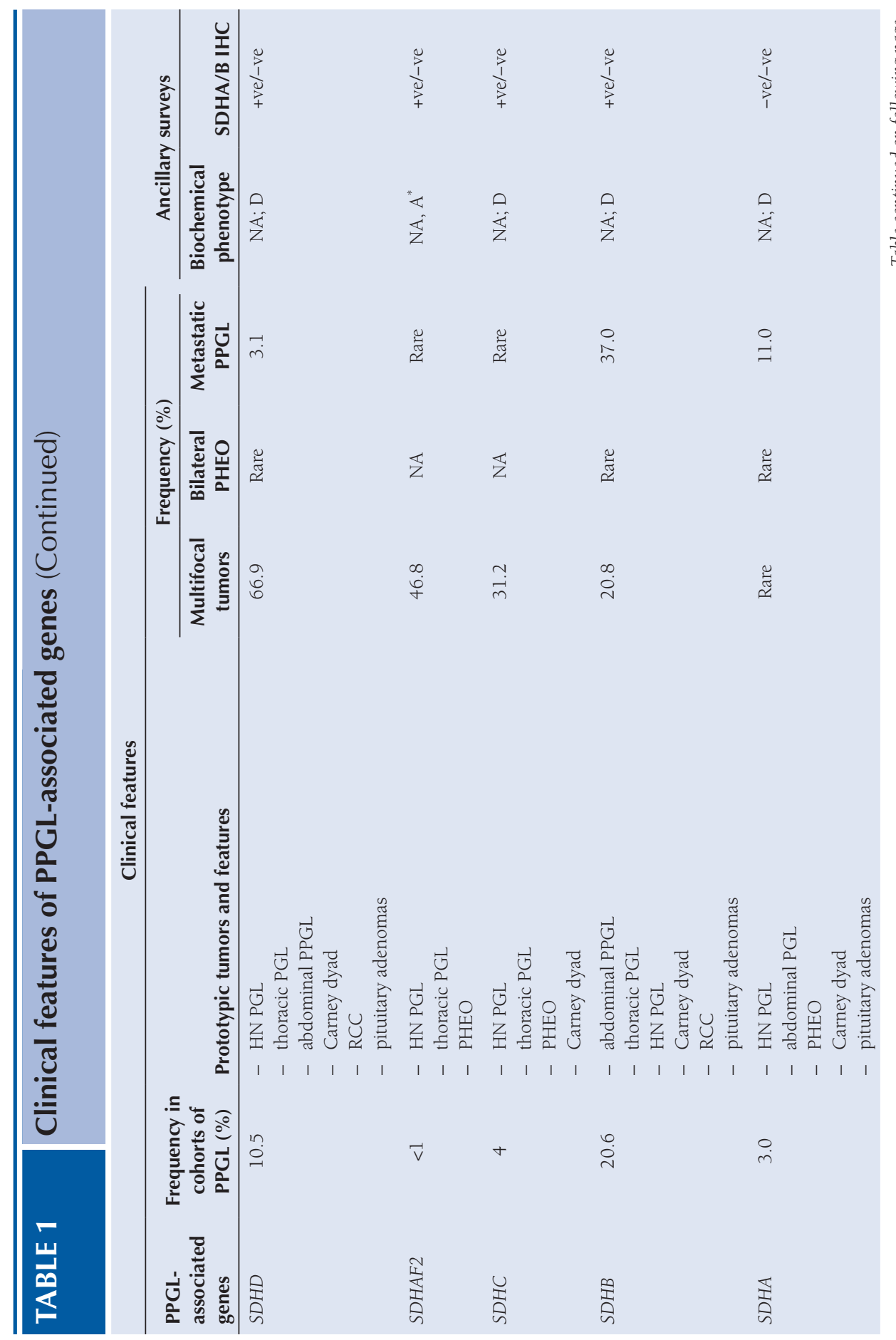




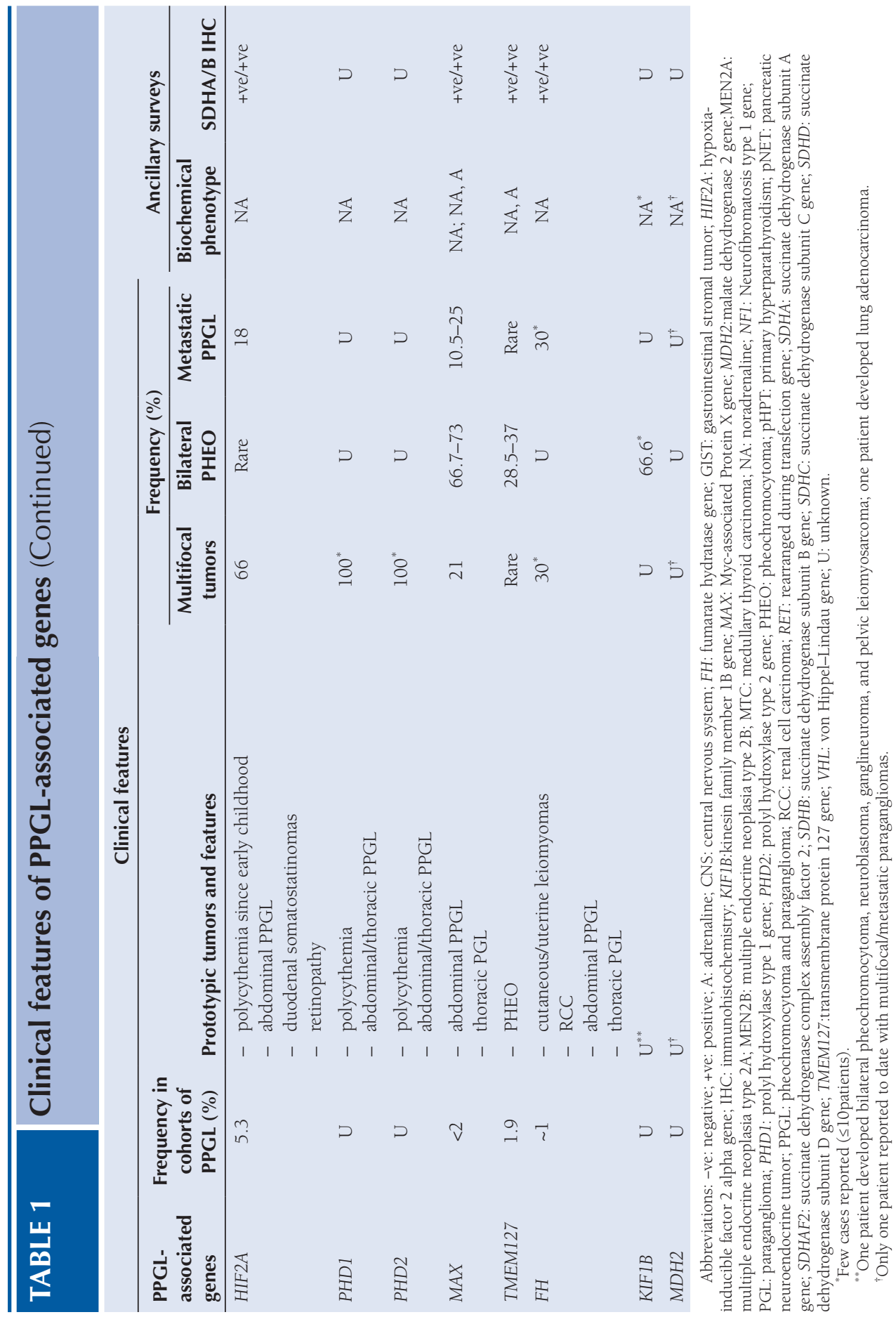


erythropoiesis, glucose metabolism, proliferation, programmed cell survival, and angiogenesis. Pseudohypoxia is a state where there is a normal oxygen supply to the tissues but a disruption in the oxygen sensing pathways (caused by gene mutations and their non-synonymous structural translated proteins), leading to an abnormal overexpression of HIF- $2 \alpha$ that promotes oncogenesis, cancer invasion, and metastasis $(31,32)$. The SDH complex (formed by its catalytic subunits $A$ and $B$, and anchorage subunits $C$ and D) and the enzymes FH and $\mathrm{MDH} 2$ catalyze the conversion of succinate to fumarate, fumarate to malate, and malate to oxaloacetate in the tricarboxylicacid cycle, respectively. Loss-offunction mutations in SDHx (SDHD, MIM *602690; SDHAF2, MIM *613019; SDHC, MIM *602413; SDHB, MIM *185470; SDHA, MIM *600857), FH (MIM *136850), and MDH2 (MIM *154100) lead to the accumulation of Krebs cycle precursors such as fumarate and succinate, which act as oncometabolites: (i) they inhibit the PHD activity, which signals HIF-2 $\alpha$ for degradation; (ii) they inhibit the factor inhibiting HIF, resulting in activation by HIF-2 $\alpha$ (and other complexed molecules) of proteins that promote gene transcription; (iii) succinate inhibits the ten eleven translocation enzymes, which are key in repressing gene transcription by silencing promoter regions through methylation processes (33). Similarly, inactivating mutations in PHD1 (MIM *606424) and PHD2 (MIM *606425) lead to a decrease in the hydroxylation (by their corresponding enzymes, PHD1 and PHD2) of HIF-2 $\alpha$, promoting its accumulation and proneoplastic activity $(15,32)$. HIF2A (MIM *603349) mutations that predispose to PPGL cause electrostatic alterations in HIF-2 $\alpha$ that impair its hydroxylation and subsequent degradation by VHL proteins $(34,35)$. Finally, VHL (MIM *608537) inactivating mutations lead to an excess of HIF-2 $\alpha$ due to the defective recognition of its hydroxylated isoform by the VHL protein and, ultimately, to cancer development and metastasis $(34,35)$.

The proto oncogene RET (MIM + 164761) encodes a tyrosine kinase transmembrane receptor that activates Ras/MAPK and PI3K/AKT pathways, which are involved in proliferation, survival, migration, and angiogenesis. Gain-offunction mutations in RET lead to a constitutive activation of the tyrosine kinase domain of its receptor, and to cancer initiation through deregulated proliferation and increased cell survival (36). NF1 (MIM *613113) is a tumor suppressor gene that encodes a GTPAse activator-neurofibromin type 1 . Neurofibromin type 1 normally inhibits Ras and its downstream activation through the mTOR kinase pathway (37). TMEM127 (MIM *613403) is also a tumor suppressor gene that translates a protein which directly inhibits the mTOR protein (38). Thus, loss-of-function mutations in NF1 and TMEM127 lead to an increased activation of the mTOR pathway and, ultimately, to enhanced cell proliferation and cancer development. MAX (MIM *154950) gene encodes a nuclear protein that acts as a transcriptional repressor of Myc. PPGL-associated MAX mutations translate a protein that cannot bind Myc, thus allowing a Myc deregulated transcriptional activity that results in cell proliferation, repression of differentiation, and angiogenesis (39). KIF1B (MIM *605995) encodes a protein that acts as a downstream effector of PHD3-induced apoptosis. Thus, loss-of-function mutations in KIF1B lead to PPGL development through cell death escape and enhanced survival $(40,41)$. 


\section{SYNDROMIC PRESENTATIONS}

PPGL may be part of one of the following syndromes: VHL, multiple endocrine neoplasia type 2 (MEN2), NF1, and those associated with mutations in PHD1/ PHD2 and HIF2A. VHL syndrome (MIM \#193300) is an autosomal dominant disease characterized by central nervous system (CNS) and retinal hemangiomas (60-80\%), renal cysts (50-70\%), clear cell renal cell carcinoma (RCC) (30\%), pancreatic neuroendocrine tumors (8-17\%) and cysts (72\%), PPGL (20\%), endolymphatic sac tumors (6-15\%), and epididymal (25-60\%) and broad ligament cystadenomas (42-45). CNS hemangiomas are the most common prototypic lesions of VHL disease, and death is usually caused by RCC and complications of CNS tumors $(42,45)$. The mean age of presentation is in the third decade of life and the penetrance of the disease reaches $90 \%$ by 65 years old (yo), but patients can show retinal hemangioblastomas or pancreatic cysts as early as 1 yo (45). According to the patient's genotype, VHL disease may be classified as type 1 (large deletions and truncating mutations of VHL that predispose to CNS hemangiomas and RCC, but not PPGL) or type 2 (missense mutations that predispose to PPGL associated with hemangioblastomas: VHL disease type 2A; hemangioblastomas and RCC: VHL disease type 2B; or only PPGL:VHL disease type 2C) $(44,45)$. In large case series of patients with PPGL, a VHL mutation is present in $9.6-17.6 \%$ of cases $(3,46)$. The mean age of PPGL presentation is 30 yo (4-58), and patients develop PHEO much more frequently than PGL (19). PPGL may be the presenting feature of the syndrome (30-55\%) and, as de novo mutations are frequent, patients may not have a remarkable personal and family history $(19,45,47)$. Thus, clinicians should bear in mind the relative high frequency of VHL mutations (46) in patients with a seemingly sporadic PPGL when ordering their genetic screening.

MEN2 is an autosomal dominant syndrome caused by germline mutations in RET, and it is classified into two subtypes according to the patient's phenotype: MEN2A (MIM \#171400) and MEN2B (MIM \#162300) (48). MEN2A is the most common subtype (95\%) and its prototypic lesions are medullary thyroid carcinoma (MTC, 97\%), PPGL (68\%), and primary hyperparathyroidism (14\%). The mean age of presentation is 40 yo and the penetrance is virtually $100 \%$ by the 8th decade of life (48-50). MEN2B is a variant characterized by an aggressive form of MTC (100\%), PPGL (59\%), marfanoid habitus, and ganglioneuromatosis of the oral mucosa and gut. It usually develops earlier than MEN2A (mean age of presentation:13-22 yo), and most patients have incurable MTC at diagnosis, as $75 \%$ of cases are sporadic and thus not amenable for cancer surveillance and timely treatment strategies $(49,51,52)$. In MEN2, PPGL are usually diagnosed concomitantly or after MTC, and PHEO is the most frequent chromaffin cell tumor, whereas PGL occurs in a small proportion of patients (4.8\%) (49). Specific mutations in RET codons 918, 883, 634, and 631 confer the highest risk for PHEO, whereas other affected codons are associated with a much lower penetrance $(50,53)$.

NF1 (MIM \#162200) is a syndrome characterized by the progressive occurrence, since birth, of cafe au lait spots ( 100\%), axillary/inguinal freckling (90\%), neurofibromas (84\%), Lisch nodules of the iris (>70\%), typical osseous lesions 
(14\%; scoliosis, sphenoid wing, and/or long bone dysplasia), and optic glioma (4\%). NF1 also predisposes to breast, lung, and colorectal carcinomas (16\%), PPGL (7.7\%), sarcomas (7\%), gastrointestinal stromal tumors, GIST (7\%), melanoma (0.1-5.4\%), and pancreatic neuroendocrine tumors (rare) (54-58). The clinical diagnosis of NFl is usually easy to establish, as the penetrance of at least two NF1 prototypic lesions is close to $100 \%$ by 8 yo (54). Similar to VHL disease and MEN2, PHEO (93.6\%) is much more frequent than PGL (6\%) in patients with NF1, and the mean age of diagnosis of PPGL is 42 yo $(19,57)$.

HIF2A mutations cause a new PPGL-associated cancer syndrome described initially in 2012 (59). This syndrome is characterized by a set of clinical features, occurring either in isolation or in combination: polycythemia since early childhood, PPGL, duodenal somatostatinomas, and retinopathy. The "Pacak-Zhuang" syndrome is considered if the patient develops polycythemia, PPGL, and somatostatinoma (60). The relative frequency of the clinical phenotypes associated with HIF2A mutations is isolated polycythemia (45.0\%), polycythemia and PPGL (14.5\%), polycythemia, PPGL, and somatostatinoma (9.6\%), isolated PPGL (22.6\%), brain hemangiomas (4.8\%, one with a concomitant PGL), and duodenal gangliocytic PGL (3.2\%) (13, 60, 61-70). The prevalence of HIF2A mutations in cohorts of PPGL is estimated to be $5.3 \%(63,65,66)$, with a median age of diagnosis of PHEO of 40 yo (range: 13-78), whereas for PGL it is 20 yo (range: 8-78) $(13,60,61-70)$. These tumors are initially benign and multiple, but they recur frequently, requiring repeated surgeries, and develop metastases, especially PGLs (60). Somatostatinomas occur only in females at the median age of diagnosis of 32 yo (range: 22-59) and they are located around duodenal ampulla. These tumors are associated with symptomatic gallbladder disease, occur in the duodenum $(100.0 \%)$ and pancreas $(50.0 \%)$, carry a considerable risk of recurrence (50.0\%) and malignancy (50.0\%), and are diagnosed after the development of PPGL (60). The majority of HIF2A mutations are somatic and thus the family history is negative. However, some patients have somatic mosaicism, where the mutation is found in tumor cells and in a fraction of normal tissues $(61,63,65,70)$. Thus, there may be a possibility of transmission of a HIF2A mutation to the next generation by an affected member who has mosaicism that includes the gametes. However, such cases have never been described until now (61). Additionally, there are seven familial cases of HIF2A mutations, but the majority had only polycythemia (60), and two non-related cases of germline mutations in adult patients with isolated PHEO (65). This evidence has led experts to develop recommendations regarding genetic testing and counseling, as well as clinical follow-up of patients with HIF2A mutations $(60,61)$.

Germline mutations in PHD1/PHD2 were reported in patients with polycythemia and PPGL $(15,71)$. The syndromes caused by these mutations are characterized by polycythemia at a later age relative to HIF2A mutation carriers and recurrent PPGL $(15,71)$. To date, only two cases of PHD2-and one case of PHD1associated PPGL have been reported in the literature $(15,71)$. The two patients with PHD2 mutations were a female and a male with an unremarkable family history who developed polycythemia by the ages of 16 yo and 30 yo, and recurrent PPGL since 39 yo (bPHEO and recurrent PGL) and 43 yo (recurrent PGL), respectively. The single case of PHD1-associated PPGL was a female with no family history who presented with polycythemia diagnosed at 6 yo and developed PPGL (bPHEO and recurrent and metastatic PGL) since 14 yo $(15,71)$. 


\section{MULTIFOCAL TUMORS}

Multifocal PPGLs occur mainly in patients with SDHx, HIF2A, PHD1/2, and FH mutations and rarely in those with MAX and VHL mutations (11, 14, 15, 46, $60,71,72)$.

Germline SDHD mutations predispose carriers to PGLl (MIM \#168000) (9). This syndrome is characterized by parasympathetic head and neck (HN) PGL (89.0\%), sympathetic thoracic PGL (16.0\%), and/or PHEO (10.5\%), with a particularly high incidence of multiple tumors $(66.9 \%)$ and recurrence of new tumors (58.2\%). The mean age of presentation is $28 \mathrm{yo}$, and the penetrance reaches $>80.0 \%$ by 40 yo (72-74). Non-chromaffin cell tumors may also occur in patients with SDHD mutations (RCC: 8\%; GIST: rare, isolated, or associated with PGLCarney dyad or Carney-Stratakis syndrome-; and pituitary adenomas: rare) (75-80). PGLl almost always manifests when the SDHD mutation is paternally inherited due to a selective somatic loss of the maternal chromosome 11. Lack of the paternal chromosome 11 does not lead to tumor initiation due to a maternal oncosuppressor locus in the $11 \mathrm{p} 15$ region (imprinted in the father) (81). Thus, the family history may show a "skip-generation" pattern of inheritance $(73,82,83)$. Very rarely, loss of the paternal $1 \mathrm{lq}$ (where SDHD allele is located) and a mitotic recombination of the maternal 1lq (carrying an SDHD mutation) with the paternal 11 p15 imprinted oncossupressor region may lead to the phenotypic expression of the disease, inherited from the mother $(73,82,83)$.

SDHB mutations cause PGL4 (MIM \#115310) (7), an autosomal dominant disorder characterized mainly by the development of sympathetic abdominal (67.0\%) and thoracic PGL (17.6\%), parasympathetic HN PGL (27.5\%), and/or PHEO (11.4\%); multifocal tumors may develop in $20.8 \%$ of patients $(72,73)$. The mean age of presentation is 34 yo, and the penetrance reaches $65.0 \%$ by 40 yo (73). Although both SDHB and SDHD mutations predispose patients to multifocal tumors, the former are more likely when the phenotype is characterized by thoracic and abdominal PPGL $(72,73)$. SDHB mutations are also associated with the development of RCC (14\%), GIST (2\%; isolated or as part of Carney dyad/ Carney-Stratakis syndrome), and pituitary adenomas (rare) (75-80).

PGL3 (MIM \#506373) is caused by mutations in SDHC gene (84). This syndrome is inherited in an autosomal dominant pattern and clinical disease usually manifest at a mean age of 46 yo; the prevalence of PPGL associated with PGL3 is $4.0 \%$ (85). Carriers of SDHC mutations develop mainly HN PGL (87.5\%) of carotid body and jugular/tympanojugular region, and less frequently thoracic PGL $(12.5 \%)$ and PHEO (rare) $(72,85,86)$. Although multifocal HN PGLs are more likely associated with SDHD mutations, this phenotype is found in $31.2 \%$ of patients with PGL3 (72). SDHC mutations are also associated with the development of RCC (rare), GIST (rare; isolated or as part of Carney dyad), and pituitary adenomas (rare) (75-80). Of interest, the epigenetic methylation of the promoter region of SDHC (at the somatic level) is the molecular signature of Carney triadGIST, PGL, and pulmonary chondroma (78).

SDHAF2 mutations were originally described in a large Dutch kindred with HN PGL, with half of the affected carriers manifesting multiple tumors $(87,88)$. PGL2 (MIM \#601650) is inherited in an autosomal dominant pattern but similar to PGL1, as SDHAF2 is maternally imprinted, clinical manifestations occur only 
when mutations are inherited from the father (88). Since the description of PGL2 in the Dutch family, only a few additional reports have been published $(10,88,89)$, and the prevalence of SDHAF2 mutations in patients with PPGL is thus considered extremely rare $(<1 \%)$ (90). Tumors develop as early as 20 yo, and the penetrance of the disease in carriers of paternally inherited mutations reaches $75 \%$ by the seventh decade of life $(10,73,89)$. The majority of patients develop carotid HN PGL (56.3\%), with multifocal tumors (HN region) detected in $46.8 \%$ of cases. Thoracic PGLs (co-occurring with HN PGL) and PHEO (single tumors) were also rarely described $(10,88,89)$.

Patients with HIF2A mutations develop PPGL at a median age of 17 yo (8-39).These tumors are recurrent, localized in the abdomen in almost all cases, and PGLs are diagnosed before or simultaneously with PHEO in $66 \%$ of cases $(13,60,61,62)$. The three patients reported to date with PHD1/PHD2 mutations developed a clinical phenotype similar to patients with HIF2A mutations (abdominal, recurrent PPGL) $(15,71)$. It is thus recommended that patients with PHD1/PHD2/HIF2A mutations should have a follow-up by imaging every 1-2 years (HIF2A: since 8 yo; PHD1/PHD2: unknown, youngest age reported is 14 yo) (60). Considering all available imaging methods, the most accurate examination to follow patients with PHD1/PHD2/HIF2A mutations is ${ }^{18} \mathrm{~F}$-fluoro dihydroxyphenylalanine ( $\left.{ }^{18} \mathrm{~F}-\mathrm{FDOPA}\right)$ positron emission tomography (PET)/ computed tomography $(\mathrm{CT})$, which reflects the importance of the genotype to individualize the care of patients with PPGL (60).

FH mutations, a cause of hereditary leiomyomatosis (cutaneous and uterine, $46 \%$ ) and renal cell cancer (47\%), were found recently to predispose carriers to PPGL (rarely, $0.83 \%$ of all PPGL) $(14,91)$. The 10 patients reported to date had a median age of diagnosis of 32 yo (6-69); eight patients developed PHEO and four patients developed PGL (three thoraco-abdominal and one head and neck) $(14,91-93)$. In a large collaborative cohort study, FH mutations were found to predispose to multifocal PPGL (30\%) with a significantly higher rate than mutations in other PPGL-associated genes (14).

$\mathrm{MDH} 2$ has been recently found as a new PPGL susceptibility gene in a 55 yo man with multiple recurrent thoracic and abdominal PGL (17). Although no further cases have been reported to date, it may be hypothesized that patients with PPGL and MDH2 mutations manifest a phenotype similar to that of patients with FH mutations, as non-synonymous enzymes coded by these genes may generate a similar disruption of Krebs cycle and proneoplastic environment.

VHL disease is rarely associated with PGL. The majority are located in the abdomen and are usually solitary $(42,44,94)$. The spectrum of prevalence of multifocal PPGL (abdominal PGL and PHEO) in VHL disease is wide across studies, from 0 to $18.8 \%(19,47,95)$. Considering that VHL is one of the most frequently mutated PPGL-associated genes (46), clinicians should take into account this gene as a cause of multifocal PPGL when patients have a negative genetic screening for SDHx mutations.

MAX mutations are a genetic cause of familial PHEO, which was discovered in 2011 in a cohort of young patients with bPHEO that tested negative to all of the main PPGL susceptibility genes (96). This finding was corroborated in a further cohort study that concluded that MAX mutations are a rare cause $(<2 \%)$ of PPGL (11). Patients with MAX mutations have a median age of diagnosis of 30.5 years (range: 17-47) and the majority (73\%) have developed the disease by 40 yo. 
Family history is present in 37\% of cases, and it shows a preferential paternal transmission of the disease (and a "skip-generation" pattern of heritability) $(11,96)$. Although no cases of multifocal PPGL were reported in the first published cohort of patients with MAX mutations (96), a further report comprising 23 PPGL patients with germline mutations in MAX showed a prevalence of thoracoabdominal PGL in association with PHEO in $21 \%$ of cases (11). Thus, although MAX is a rare cause of multifocal PPGL, it should also be considered in the genetic screening of patients with multifocal PPGL after more common gene mutations have been excluded.

\section{METASTATIC DISEASE}

Malignant PPGL is considered when there is evidence of metastasis (e.g., bone, lymph node) (1). Its prevalence is reported to be $10.0 \%$, considering all age groups $(3,19,46)$, and tumors larger than $4 \mathrm{~cm}$ or extra-adrenal in location, pediatric age, and SDHB mutations are features that confer a higher risk of malignancy $(97,98)$. The majority of metastatic PPGLs are associated with SDHB mutations, and less frequently with NF1, SDHA, HIF2A, MAX, and FH mutations (5, 7, 11, $14,19,60,72,90,99,100)$.

PGL4 is associated with the development of metastatic PPGL in $37.0 \%$ of patients across the age spectrum $(72,73)$. Thoracic and abdominal sympathetic tumors carry the highest risk of metastasis, mainly to the lymph nodes, liver, lungs, and bones $(7,72)$. Thus, patients with SDHB mutations need a rigorous lifetime follow-up for timely detection of metastatic disease. When comparing all the available functional imaging techniques for this purpose, the most accurate for patients with $S D H x$ mutations is $\left[{ }^{68} \mathrm{Ga}\right]-D O T A(0)-\operatorname{Tyr}(3)$-octreotate $\left(\left[{ }^{68} \mathrm{Ga}\right]\right.$ DOTATATE) PET/CT, followed by $\left[{ }^{18} \mathrm{~F}\right]$-fluoro-2-deoxy-D-glucose PET/CT (101). These data underline the importance of the patient genotype for the delivery of precision medicine.

NF1 is a cause of PPGL in less than 3\% of cohorts of patients with these tumors, but it is associated with a considerable rate of metastatic PPGL (5.4-12\%) $(19,99,100)$, with a large review of 148 patients with NFl-associated PPGL reporting $11.5 \%$ (5). The majority of cases present at diagnosis with metastasis in the liver, lungs, and bones $(5,19,99,100)$.

PGL5 (MIM \#614165) is caused by mutations in the subunit A of the SDH complex (6), which are found in 3.0\% of all PPGL patients (90). This syndrome has a median age of presentation of 33 yo, and the penetrance reaches $38 \%$ by 40 yo $(6,24,90)$. SDHA mutations predispose patients to HN PGL $(38.9 \%)$, abdominal PGL (27.8\%), and unilateral PHEO (24.0\%) (6, 24, 25, 90). SDHA mutations also confer susceptibility to GIST (isolated or as part of Carney dyad) and pituitary adenomas (rare) (75-80). In the largest case series (38 patients) of PPGL associated-SDHA mutations, the reported prevalence of metastatic PPGL was $11 \%(90)$.

HIF2A mutations are associated with metastatic PPGL in 18\% of patients, and the few cases reported were abdominal PGL (13, 60-70). However, it seems that the aggressive behavior of metastatic PPGL seen in patients with SDHBassociated tumors is not present in patients with HIF2A mutations (60). 
In patients with MAX mutations, the rate of metastatic PPGL is $10.5-25.0 \%$, considering the two largest case series published. All cases occurred in patients with PHEO, and the majority showed metastasis at diagnosis $(11,96)$.

Taking into account the 10 reported patients with PPGL and FH mutations, metastatic disease was described in three of these cases (30\%) (14, 91-93), and in a large cohort study of patients with PPGL, FH mutations were associated with a significantly higher risk of malignancy when compared with mutations in other PPGL susceptibility genes (14).

The single case of MDH2-associated multifocal PGL reported to date was also found to be malignant (17).

Thus, although patients with NF1, SDHA, HIF2A, MAX, FH, and MDH2 mutations represent a minority among PPGL cases, clinicians should bear in mind the potential for metastatic behavior of tumors associated with these genotypes in the long-term care.

\section{BILATERAL PHEOCHROMOCYTOMA}

bPHEO often occurs in association with MEN2 or VHL disease and is rarely associated with MAX, TMEM127, and KIF1B mutations (11, 16, 48-52, 95, 102-104).

Patients with MEN2 are prone to bPHEO (synchronous or metachronous) in $47-66 \%$ of cases (48-52). The highest risk RET mutations for developing PHEO (those that affect RET codons 918, 883, 634, 631, and 618) are also associated with a high incidence of bPHEO $(50,53,104)$. After adrenalectomy for a unilateral tumor, the mean follow-up time for a metachronous PHEO to develop is 3.6-5.2 years $(49,50,105)$.

VHL disease is associated with bPHEO in 29-43.5\% of cases (19, 47, 95); additionally, in patients presenting with a unilateral PHEO, a contralateral tumor may develop in 19\% of cases at a mean follow-up time of 4 years $(47,94)$. Finally, VHL mutations are most likely in patients with an apparently nonsyndromic bPHEO included in large cohort studies, due to the higher incidence of VHL compared with RET mutations (46).

TMEM127 mutations are a rare cause of PPGL $(<2 \%)$ initially described in a cohort of patients older than the expected age for individuals with hereditary PPGL (12). In addition, it was found that family history was absent in nearly half of cases, which may hinder the suspicion for TMEM127 mutations in clinical grounds (12). In larger case series, the median age of diagnosis was reported to be 41.5 yo $(21-75)$, and the cumulative penetrance for clinical disease reached $32 \%$ by 65 yo $(90,102,103)$. Patients with TMEM127 mutations usually present with a unilateral PHEO, but have also a high rate of bPHEO (28.5-37\%). They have a low incidence of PGL and metastatic disease (rare cases) $(93,102,103)$.

MAX mutations are associated with a particularly high incidence of bPHEO (66.7-73\%), considering the three largest case series published to date $(11,90,96)$.

KIF1B germline mutations were initially reported in a family with bPHEO occurring in a female proband and her grandfather (age of diagnosis: 22 and 70 yo, respectively) (16). An additional case of a 54 yo female with a unilateral PHEO was reported later in a cohort of PPGL studied by targeted next-generation 
sequencing (NGS) (106). Thus, although few cases of KIF1B-associated PPGL have been described to assume a propensity of patients with mutations in this gene to develop bPHEO, clinicians should bear in mind the possibility of a KIF1B mutation when more common genes associated with this phenotype have been found to be normal.

\section{PEDIATRIC PPGL}

Considering the largest case series of pediatric patients ( 363 patients $\leq 18$ yo) with PPGL published to date, the prevalence of genetic mutations was found to be 66.8-80.4\% (72, 107-109). The majority of PPGLs developing at a pediatric age occur in association with SDHB, SDHD, and VHL mutations $(74,107)$, and the higher frequency of hereditary cases at a pediatric compared with adult age is due to an excess of mutations in PPGL-susceptibility genes of cluster 1 (74). From a clinical point of view, it is worth noting that pediatric patients have a higher incidence of extra-adrenal, multifocal, recurrent, and metastatic tumors compared with adults (74). Thus, considering the very high prevalence of gene mutations in patients with PPGL at a pediatric age, all cases with $\leq 18$ yo should be considered for genetic screening $(18,107,109)$.

\section{BIOCHEMICAL PHENOTYPE}

The pattern of catecholamine secretion by the PPGL is recognized as a signature of its genetic background. Indeed, cluster 1 gene mutations are associated with a noradrenergic and/or dopaminergic phenotype of tumoral secretion, whereas gene mutations in cluster 2 are associated with an adrenergic and/or noradrenergic phenotype (110). Under hypoxia (or pseudohypoxia) states, HIF-2a activates enzymes (e.g., tyrosine hydroxylase, dopamine ß-hydroxylase, and dopa decarboxylase) that favor the production of norepinephrine in the catecholamine production pathway and, in parallel, decreases the expression of phenylethanolamine N-methyltransferase, the enzyme that converts norepinephrine to epinephrine (110). In agreement with these findings, PPGLs associated with VHL, SDHx, HIF2A/PHD1/PHD2, FH, and MDH2 mutations produce and secrete predominantly norepinephrine/normetanephrine, but rarely epinephrine/metanephrine (PPGL-associated with VHL mutations do not secrete epinephrine/metanephrine) $(14,17,23,60)$. However, PHEOs associated with SDHx mutations also produce and/or secrete dopamine/methoxytyramine, which is rarely detected in VHL disease (23). On the contrary, PPGLs associated with RET or NF1 mutations (cluster 2) induce an increase in phenylethanolamine N-methyltransferase and usually produce and secrete norepinephrine/normetanephrine and epinephrine/ metanephrine $(23,110)$. The discriminatory rate between the pattern of catecholamine secretion between cluster 1 (VHL/SDHx-associated PPGL-normetanephrine but not metanephrine) and cluster 2 (NF1/RET-associated PPGL-normetanephrine and metanephrine) genes was found to be 99.0\%. VHL and SDHx-associated PPGLs can be further discriminated in $78.0 \%$ of cases by the levels of 
methoxytyramine (elevated only in SDHx-associated PPGL) (23). MAX-associated PPGLs secrete high levels of normetanephrine and moderate levels of metanephrine $(11,18)$. TMEM127-associated PPGLs have a mixed pattern of catecholamine secretion (normetanephrine and metanephrine) (102).

\section{IMMUNOHISTOCHEMICAL PHENOTYPE}

The immunohistochemical analysis of SDHA and SDHB protein expression in tumor samples may be very useful to individualize the genetic screening of patients with PPGL (24-26). Negative staining for SDHB immunohistochemistry (IHC) suggests an SDHx mutation, whereas a negative staining for SDHA IHC implies an SDHA mutation $(24,111)$. False negatives (positive or weakly positive staining) may occur in SDHD-related tumors for SDHB staining (112), and SDHD IHC may aid in these cases (positive staining predicts SDHx mutations) (113). RET, HIF2A, MAX, TMEM127, FH, NF1 (95.0\%) and VHL (84.0\%) associatedPPGLs show positive IHC for SDHA/B, and thus this is a useful tool to aid in the selection of genetic screening, considering the full clinical setting $(24,93,111)$. Although the rarity of FH-associated PPGL precludes the validation of FH IHC, there is evidence that the pattern of FH staining may also aid with the decision to proceed with FH analysis, as tumor samples with known mutations in this gene have negative staining for FH, whereas PPGLs associated with SDHB/C/D, VHL, and RET retain a positive staining for this enzyme (111).

\section{FUNCTIONAL IMAGING}

Functional imaging is used in the management of PPGL to (i) localize the primary tumor, (ii) define the tumor burden of a metastatic PPGL that may be missed on CT or MRI surveys, and (iii) characterize the metabolic activity of PPGL for therapeutic purposes $(18,114)$. The ${ }^{18} \mathrm{~F}-\mathrm{FDOPA} \mathrm{PET} / \mathrm{CT}$ is a highly accurate functional imaging tool in the investigation of PPGL (27). However, false negative results may infrequently occur, mainly with abdominal tumors. These missed lesions on ${ }^{18}$ F-FDOPA PET/CT are often associated with SDHB and SDHD mutations, and it is worth to consider specific genetic screening for SDHx mutations in ${ }^{18} \mathrm{~F}-\mathrm{FDOPA}$ PET/CT negative PPGL $(27,114)$.

\section{NEXT-GENERATION SEQUENCING}

Targeted NGS is a technology that processes DNA samples for simultaneous parallel sequencing of multiple genes $(115,116)$. Considering the high number of PPGL-related genes, NGS is attractive in this setting. Indeed, the application of this tool in cohorts of patients with PPGL has proved to be faster with lower costs compared with the conventional Sanger sequencing technique (117, 118), and NGS will probably replace the sequential genetic screening based on the clinical phenotype in a near future. However, some limitations of NGS may need to be 
resolved before its full implementation in the everyday practice, namely, the clinical relevance of variants of uncertain significance or methodological errors induced by repetitive DNA sequences and pseudogenes (117-119). Additionally, in patients presenting with the full manifestations of a well-known syndrome, targeted conventional sequencing of the gene associated with that syndrome may be more appropriate instead of an NGS panel of several genes that have never been linked to that clinical scenario, and it may save costs. Finally, NGS is not yet available in or affordable by many countries, and thus the knowledge regarding PPGL genotype-phenotype correlations remains very useful for a cost-effective genetic screening.

\section{CONCLUSIONS}

Careful genetic screening is part of the standards of care of patients with PPGL. First, the possibility of a genetic mutation is close to $50 \%$, and it reaches $80 \%$ in some age groups ( $\leq 18$ yo) $(2,3,74,107-109)$. Second, finding a specific genotype that is associated with a predisposition to the development of multifocal/ recurrent (e.g., SDHx, HIF2A/PHD1/PHD2, and FH mutations) or metastatic PPGL (e.g., SDHB, MAX, and FH mutations), and other non-chromaffin cell tumors (e.g., duodenal somatostatinomas in HIF2A mutations; renal cell cancer in $\mathrm{VHL}$ ), is paramount to tailor the diagnosis, treatment, and follow-up strategies in patients with PPGL $(14,18,60)$. With the expanding genetic landscape of PPGL, new genes (e.g., FH, MDH2, and HIF2A mutations) are being added, which predispose patients to the development of chromaffin and non-chromaffin cell tumors with characteristic biological behaviors $(14,17,60)$. This evidence emphasizes the importance of a comprehensive sequential genetic screening and the individualized strategies that may follow the discovery of a specific genotype in terms of diagnosis, treatment, long-term follow-up, and genetic counseling.

Conflict of interest: The authors declare no potential conflicts of interest with respect to research, authorship, and/or publication of this book chapter.

Copyright and permission statement: We confirm that the materials included in this chapter do not violate copyright laws. Where relevant, appropriate permissions have been obtained from the original copyright holder(s). All original sources have been appropriately acknowledged and/or referenced.

\section{REFERENCES}

1. DeLellis RA, Lloyd RV, Heitz PU, Eng C. Pathology and genetics of tumors of endocrine organs. Lyon: IARC Press; 2004. 147 p.

2. Maher ER, Eng C. The pressure rises: Update on the genetics of phaeochromocytoma. Hum Mol Genet. 2002 Oct;11(20):2347-54. http://dx.doi.org/10.1093/hmg/11.20.2347

3. Buffet A, Venisse A, Nau V, Roncellin I, Boccio V, Le Pottier N, et al. A decade (2001-2010) of genetic testing for pheochromocytoma and paraganglioma. Horm Metab Res. 2012 May;44(5):359-66. http://dx.doi.org/10.1055/s-0032-1304594 
4. Neumann HP, Berger DP, Sigmund G, Blum U, Schmidt D, Parmer RJ, et al. Pheochromocytomas, multiple endocrine neoplasia type 2, and von Hippel-Lindau disease. N Engl J Med. 1993 Nov;329(21):1531-8. http://dx.doi.org/10.1056/NEJM199311183292103

5. Walther MM, Herring J, Enquist E, Keiser HR, Linehan WM. Von Recklinghausen's disease and pheochromocytoma. J Urol. 1999 Nov;162(5):1582-6. http://dx.doi.org/10.1016/S0022-5347(05)68171-2

6. Burnichon N, Briere JJ, Libe R, Vescovo L, Rivière J, Tissier F, et al. SDHA is a tumor suppressor gene causing paraganglioma. Hum Mol Genet. 2010 Aug;19(15):3011-20. http://dx.doi.org/10.1093/ hmg/ddq206

7. Gimenez-Roqueplo AP, Favier J, Rustin P, Rieubland C, Crespin M, Nau V, et al. Mutations in the SDHB gene are associated with extra-adrenal and/or malignant phaeochromocytomas. Cancer Res. 2003 Sept;63(17):5615-21.

8. Peczkowska M, Cascon A, Prejbisz A, Kuraszek A, Cwikła BJ, Furmanek M, et al. Extra-adrenal and adrenal pheochromocytomas associated with a germline SDHC mutation. Nat Clin Pract Endocrinol Metab. 2008 Feb;4(2):111-15. http://dx.doi.org/10.1038/ncpendmet0726

9. Baysal BE, Ferrell RE, Willett-Brozick JE, Lawrence EC, Myssiorek D, Bosch A, et al. Mutations in SDHD, a mitochondrial complex II gene, in hereditary paraganglioma. Science. 2000;287(5454): 848-51. http://dx.doi.org/10.1126/science.287.5454.848

10. Casey R, Garrahy A, Tuthill A, O'Halloran D, Joyce C, Casey MB, et al. Universal genetic screening uncovers a novel presentation of an SDHAF2 mutation. J Clin Endocrinol Metab. 2014 Jul;99(7):E1392-6. http://dx.doi.org/10.1210/jc.2013-4536

11. Burnichon N, Cascon A, Schiavi F, Morales NP, Comino-Méndez I, Abermil N, et al. MAX mutations cause hereditary and sporadic pheochromocytoma and paraganglioma. Clin Cancer Res. 2012 May;18(10):2828-37.

12. Qin Y, Yao L, King EE, Buddavarapu K, Lenci RE, Chocron ES, et al. Germline mutations in TMEM127 confer susceptibility to pheochromocytoma. Nat Genet. 2010 Mar;42(3):229-33. http://dx.doi. org/10.1038/ng.533

13. Zhuang Z, Yang C, Lorenzo F, Merino M, Fojo T, Kebebew E, et al. Somatic HIF2A gain-of-function mutations in paraganglioma with polycythemia. N Engl J Med. 2012 Sep;367(10):922-30. http:// dx.doi.org/10.1056/NEJMoal205119

14. Castro-Vega LJ, Buffet A, De Cubas AA, Cascón A, Menara M, Khalifa E, et al. Germline mutations in FH confer predisposition to malignant pheochromocytomas and paragangliomas. Hum Mol Genet. 2014 May;23(9):2440-6. http://dx.doi.org/10.1093/hmg/ddt639

15. Yang C, Zhuang Z, Fliedner SM, Shankavaram U, Sun MG, Bullova P, et al. Germ-line PHDl and PHD2 mutations detected in patients with pheochromocytoma/paraganglioma-polycythemia. J Mol Med (Berl). 2015 Jan;93(1):93-104. http://dx.doi.org/10.1007/s00109-014-1205-7

16. Yeh IT, Lenci RE, Qin Y, Buddavarapu K, Ligon AH, Leteurtre E, et al. A germline mutation of the KIF1B beta gene on 1p36 in a family with neural and nonneural tumors. Hum Genet. 2008 Oct;124(3):279-85. http://dx.doi.org/10.1007/s00439-008-0553-1

17. Cascon A, Comino-Méndez I, Curras-Freixes M, de Cubas AA, Contreras L, Richter S, et al. Wholeexome sequencing identifies MDH2 as a new familial paraganglioma gene. J Natl Cancer Inst. 2015 Mar;107(5):1-5.

18. Lenders JW, Duh QY, Eisenhofer G, Gimenez-Roqueplo AP, Grebe SK, Murad MH, et al. Pheochromocytoma and paraganglioma: An endocrine society clinical practice guideline. J Clin Endocrinol Metab. 2014 Jun;99(6):1915-42. http://dx.doi.org/10.1093/jnci/djv053

19. Welander J, Soderkvist P, Gimm O. Genetics and clinical characteristics of hereditary pheochromocytomas and paragangliomas. Endocr Relat Cancer. 2011 Dec;18(6):R253-76. http://dx.doi. org/10.1530/ERC-11-0170

20. Neumann HP, Bausch B, McWhinney SR, Bender BU, Gimm O, Franke G, et al. Germ-line mutations in nonsyndromic pheochromocytoma. N Engl J Med. 2002 May;346(19):1459-66. http://dx.doi. org/10.1056/NEJMoa020152

21. Erlic Z, Rybicki L, Peczkowska M, Golcher H, Kann PH, Brauckhoff M, et al. Clinical predictors and algorithm for the genetic diagnosis of pheochromocytoma patients. Clin Cancer Res. 2009 Oct;15(20):6378-85. http://dx.doi.org/10.1158/1078-0432.CCR-09-1237 
22. Crona J, Nordling M, Maharjan R, Granberg D, Stålberg P, Hellman P, et al. Integrative genetic characterization and phenotype correlations in pheochromocytoma and paraganglioma tumors. PLoS One. 2014 Jan;9(1):E86756. http://dx.doi.org/10.1371/journal.pone.0086756

23. Eisenhofer G, Lenders JW, Timmers H, Siegert G, Bornstein SR, Friberg P, et al. Measurements of plasma methoxytyramine, normetanephrine, and metanephrine as discriminators of different hereditary forms of pheochromocytoma. Clin Chem. 2011 Jul;57(3):411-20. http://dx.doi.org/10.1373/ clinchem.2010.153320

24. Papathomas TG, Oudijk L, Persu A, Gill AJ, van Nederveen F, Tischler AS, et al. SDHB/SDHA immunohistochemistry in pheochromocytomas and paragangliomas: A multicenter interobserver variation analysis using virtual microscopy: A Multinational Study of the European Network for the Study of Adrenal Tumors (ENS@T). Mod Pathol. 2015 Jun;28(6):807-21. http://dx.doi.org/10.1038/ modpathol.2015.41

25. Korpershoek E, Favier J, Gaal J, Burnichon N, van Gessel B, Oudijk L, et al. SDHA immunohistochemistry detects germline SDHA gene mutations in apparently sporadic paragangliomas and pheochromocytomas. J Clin Endocrinol Metab. 2011 Sep;96(9):E1472-6. http://dx.doi.org/10.1210/ jc.2011-1043

26. Gill AJ, Benn DE, Chou A, Clarkson A, Muljono A, Meyer-Rochow GY, et al. Immunohistochemistry for SDHB triages genetic testing of SDHB, SDHC, and SDHD in paraganglioma-pheochromocytoma syndromes. Hum Pathol. 2010 Mar;41(6):805-14. http://dx.doi.org/10.1016/j.humpath.2009.12.005

27. Gabriel S, Blanchet EM, Sebag F, et al. Functional characterization of nonmetastatic paraganglioma and pheochromocytoma by (18) F-FDOPA PET: Focus on missed lesions. Clin Endocrinol (Oxf). 2013 Aug;79(2):170-7. http://dx.doi.org/10.1111/cen.12126

28. Gimenez-Roqueplo AP, Dahia PL, Robledo M. An update on the genetics of paraganglioma, pheochromocytoma, and associated hereditary syndromes. Horm Metab Res. 2012 Feb;44(5):328-33. http:// dx.doi.org/10.1055/s-0031-1301302

29. Jochmanova I, Pacak K. Pheochromocytoma: The first metabolic endocrine cancer. Clin Cancer Res. 2016 Oct;22(20):5001-11. http://dx.doi.org/10.1158/1078-0432.CCR-16-0606

30. Fishbein L, Leshchiner I, Walter V, Danilova L, Robertson AG, Johnson AR, et al. Comprehensive molecular characterization of pheochromocytoma and paraganglioma. Cancer Cell. 2017 Feb;31(2):181-93.

31. Shankavaram U, Fliedner SM, Elkahloun AG, Barb JJ, Munson PJ, Huynh TT, et al. Genotype and tumor locus determine expression profile of pseudohypoxic pheochromocytomas and paragangliomas. Neoplasia. 2013 Apr;15(4):435-37. http://dx.doi.org/10.1593/neo.122132

32. Jochmanova I, Yang C, Zhuang Z, Pacak K. Hypoxia-inducible factor signaling in pheochromocytoma: Turning the rudder in the right direction. J Natl Cancer Inst. 2013 Sep;105(17):1270-83. http:// dx.doi.org/10.1093/jnci/djt201

33. Lussey-Lepoutre C, Buffet A, Gimenez-Roqueplo A, Favier J. Mitochondrial deficiencies in the predisposition to paraganglioma. Metabolites. 2017 May;7(17):1-13. http://dx.doi.org/10.3390/ metabo7020017

34. Pollard PJ, Briere JJ, Alam NA, Barwell J, Barclay E, Wortham NC, et al. Accumulation of Krebs cycle intermediates and over-expression of HIFlalpha in tumors which result from germline FH and SDH mutations. Hum Mol Genet. 2005 Aug;14(15):2231-9. http://dx.doi.org/10.1093/hmg/ddi227

35. Yang C, Sun MG, Matro J, Huynh TT, Rahimpour S, Prchal JT, et al. Novel HIF2A mutations disrupt oxygen sensing, leading to polycythemia, paragangliomas, and somatostatinomas. Blood. 2013 Mar;121(13):2563-6. http://dx.doi.org/10.1182/blood-2012-10-460972

36. Ibanez CF. Structure and physiology of the RET receptor tyrosine kinase. Cold Spring Harb Perspect Biol. 2013 Feb;5(2):pii:a009134. http://dx.doi.org/10.1101/cshperspect.a009134

37. Johannessen CM, Johnson BW, Williams SM, Chan AW, Reczek EE, Lynch RC, et al. TORCl is essential for NFl-associated malignancies. Curr Biol. 2008 Jan;18(1):56-2. http://dx.doi.org/10.1016/j. cub.2007.11.066

38. Jiang S, Dahia PL. Minireview: The busy road to pheochromocytomas and paragangliomas has a new member, TMEM127. Endocrinology. 2011 Jun; 152:2133-40. http://dx.doi.org/10.1210/ en.2011-0052 
39. Cascon A, Robledo M. MAX and MYC: A heritable breakup. Cancer Res. 2012 Jul;72(13):3119-24. http://dx.doi.org/10.1158/0008-5472.CAN-11-3891

40. Lee S, Nakamura E, Yang H, Wei W, Linggi MS, Sajan MP, et al. Neuronal apoptosis linked to EgIN3 prolyl hydroxylase and familial pheochromocytoma genes: Developmental culling and cancer. Cancer Cell. 2005 Aug;8:155-67. http://dx.doi.org/10.1016/j.ccr.2005.06.015

41. Schlisio S, Kenchappa RS, Vredeveld LC, George RE, Stewart R, Greulich H, et al. The kinesin KIF1Bacts downstream from EgIN3 to induce apoptosis and is a potential 1p36 tumor suppressor. Genes Dev. 2008 Apr 1;22(7):884-93. http://dx.doi.org/10.1101/gad.1648608

42. Maher ER, Yates JR, Harries R, Benjamin C, Harris R, Moore AT, et al. Clinical features and natural history of von Hippel-Lindau disease. Q J Med. 1990 Nov;77(283):1151-63. http://dx.doi.org/10.1093/ qjmed/77.2.1151

43. Maher ER, Kaelin WG, Jr. von Hippel-Lindau disease. Medicine (Baltimore). 1997 Nov;76(6):381-91. http://dx.doi.org/10.1097/00005792-199711000-00001

44. Maher ER, Neumann HP, Richard S. von Hippel-Lindau disease: A clinical and scientific review. Eur J Hum Genet. 2011 Jun;19(6):617-23. http://dx.doi.org/10.1038/ejhg.2010.175

45. Varshney N, Kebede AA, Owusu-Dapaah H, Lather J, Kaushik M, Bhullar J. A review of Von Hippel-Lindau syndrome. J Kidney Cancer VHL. 2017 Aug;4(3):20-9. http://dx.doi.org/10.15586/ jkcvhl.2017.88

46. Mannelli M, Castellano M, Schiavi F, Filetti S, Giacche M, Mori L, et al. Clinically guided genetic screening in a large cohort of Italian patients with pheochromocytomas and/or functional or nonfunctional paragangliomas. J Clin Endocrinol Metab. 2009 Feb;94(5):1541-7. http://dx.doi.org/10.1210/ jc. 2008-2419

47. Baghai M, Thompson GB, Young WF, Grant CS, Michelis VV; van Heerden JA. Pheochromocytomas and paragangliomas in von Hippel-Lindau disease: A role for laparoscopic and cortical-sparing surgery. Arch Surg. 2002 Jun;137:682-9. http://dx.doi.org/10.1001/archsurg.137.6.682

48. Brandi ML, Gagel RF, Angeli A, Bilezikian JP, Beck-Peccoz P, Bordi C, et al. Guidelines for diagnosis and therapy of MEN type 1 and type 2. J Clin Endocrinol Metab. 2001 Dec;86(12):5658-71. http:// dx.doi.org/10.1210/jcem.86.12.8070

49. Iihara M, Yamashita T, Okamoto T, Kanbe M, Yamazaki K, Egawa S, et al. A nationwide clinical survey of patients with multiple endocrine neoplasia type 2 and familial medullary thyroid carcinoma in Japan. Jpn J Clin Oncol. 1997 Jun;27(3):128-34. http://dx.doi.org/10.1093/jjco/27.3.128

50. Machens A, Brauckhoff M, Holzhausen HJ, Thanh PN, Lehnert H, Dralle H. Codon-specific development of pheochromocytoma in multiple endocrine neoplasia type 2. J Clin Endocrinol Metab. 2005 Jul;90(7):3999-4003. http://dx.doi.org/10.1210/jc.2005-0064

51. O'Riordain DS, O'Brien T, Crotty TB, Gharib H, Grant CS, van Heerden JA. Multiple endocrine neoplasia type 2B: More than an endocrine disorder. Surgery. 1995 Dec;118(6):936-42. http://dx.doi. org/10.1016/S0039-6060(05)80097-2

52. Leboulleux S, Travagli JP, Caillou B, Laplanche A, Bidart JM, Schlumberger M, et al. Medullary thyroid carcinoma as part of a multiple endocrine neoplasia type 2B syndrome: Influence of the stage on the clinical course. Cancer. 2002 Jan;1(94):44-50. http://dx.doi.org/10.1002/cncr. 10205

53. Wells SA, Jr, Asa SL, Dralle H, Elisei R, Evans DB, Gagel RF, et al. Revised American Thyroid Association guidelines for the management of medullary thyroid carcinoma. Thyroid. 2015 Jun;25(6):567-610. http://dx.doi.org/10.1089/thy.2014.0335

54. DeBella K, Szudek J, Friedman JM. Use of the national institutes of health criteria for diagnosis of neurofibromatosis 1 in children. Pediatrics. 2000 Mar;105(3 Pt 1):608-14. http://dx.doi.org/10.1542/ peds. 105.3.608

55. Boyd KP, Korf BR, Theos A. Neurofibromatosis type 1. J Am Acad Dermatol. 2009 Jul;61(1):1-14; quiz 15-16. http://dx.doi.org/10.1016/j.jaad.2008.12.051

56. Zoller ME, Rembeck B, Oden A, Samuelsson M, Angervall L. Malignant and benign tumorsin patients with neurofibromatosis type 1 in a defined Swedish population. Cancer. 1997 Jun;79(11):2125-31. http:// dx.doi.org/10.1002/(SICI)1097-0142(19970601)79:11\%3C2125::AID-CNCR9\%3E3.3.CO;2-B

57. Képénékian L, Mognetti T, Lifante JC, Giraudet AL, Houzard C, Pinson S, et al. Interest of systematic screening of pheochromocytoma in patients with neurofibromatosis type 1. Eur J Endocrinol. 2016 Oct;175(4):335-44. http://dx.doi.org/10.1530/EJE-16-0233 
58. Perren A, Wiesli P, Schmid S, Montani M, Schmitt A, Schmid C, et al. Pancreatic endocrine tumors are a rare manifestation of the neurofibromatosis type 1 phenotype: Molecular analysis of a malignant insulinoma in a NF-1 patient. Am J Surg Pathol. 2006 Aug;30(8):1047-51. http://dx.doi. org/10.1097/00000478-200608000-00018

59. Favier J, Buffet A, Gimenez-Roqueplo AP. HIF2A mutations in paraganglioma with polycythemia. N Engl J Med. 2012 Nov;367(22):2161-2. http://dx.doi.org/10.1056/NEJMc1211953

60. Darr R, Nambuba J, Del Rivero J, Janssen I, Merino M, Todorovic M, et al. Novel insights into the polycythemia-paraganglioma-somatostatinoma syndrome. Endocr Relat Cancer. 2016 Dec;23(12): 899-908. http://dx.doi.org/10.1530/ERC-16-0231

61. Buffet A, Smati S, Mansuy L, Ménara M, Lebras M, Heymann MF, et al. Mosaicism in HIF2A-related polycythemia-paraganglioma syndrome. J Clin Endocrinol Metab. 2014 Feb;99(2):E369-73. http:// dx.doi.org/10.1210/jc.2013-2600

62. Taieb D, Yang C, Delenne B, Zhuang Z, Barlier A, Sebag F, et al. First report of bilateral pheochromocytoma in the clinical spectrum of HIF2A-related polycythemia-paraganglioma syndrome. J Clin Endocrinol Metab. 2013 May;98(5):E908-13. http://dx.doi.org/10.1210/jc.2013-1217

63. Comino-Mendez I, de Cubas AA, Bernal C, Álvarez-Escolá C, Sanchéz-Malo C, Ramirez-Tortosa CL, et al. Tumoral EPAS1 (HIF2A) mutations explain sporadic pheochromocytoma and paraganglioma in the absence of erythrocytosis. Hum Mol Genet. 2013 Jun;22(11):2169-76. http://dx.doi.org/10.1093/ hmg/ddt069

64. Toyoda H, Hirayama J, Sugimoto Y, Uchida K, Ohishi K, Hirayama M, et al. Polycythemia and paraganglioma with a novel somatic HIF2A mutation in a male. Pediatrics. 2014 Jun;133(6):E1787-91. http://dx.doi.org/10.1542/peds.2013-2419

65. Toledo RA, Qin Y, Srikantan S, Morales NP, Li Q, Deng Y, et al. In vivo and in vitro oncogenic effects of HIF2A mutations in pheochromocytomas and paragangliomas. Endocr Relat Cancer. 2013 May;20(3):349-59. http://dx.doi.org/10.1530/ERC-13-0101

66. Welander J, Andreasson A, Brauckhoff M, Bäckdahl M, Larsson C, Gimm O, et al. Frequent EPAS1/ HIF2alpha exons 9 and 12 mutations in non-familial pheochromocytoma. Endocr Relat Cancer. 2014 Jun;21(3):495-504. http://dx.doi.org/10.1530/ERC-13-0384

67. Zhuang Z, Yang C, Ryska A, Ji Y, Hou Y, Graybill SD, et al. HIF2A gain-of-function mutations detected in duodenal gangliocytic paraganglioma. Endocr Relat Cancer. 2016 May;23(5):L13-16. http:// dx.doi.org/10.1530/ERC-16-0148

68. Taieb D, Barlier A, Yang C, Pertuit M, Tchoghandjian A, Rochette C, et al. Somatic gain-of-function HIF2A mutations in sporadic central nervous system hemangioblastomas. J Neurooncol. 2016 Feb;126(3):473-81. http://dx.doi.org/10.1007/s11060-015-1983-y

69. Lorenzo FR, Yang C, Ng Tang Fui M, Vankayalapati H, Zhuang Z, Huynh T, et al. A novel EPAS1/ HIF2A germline mutation in a congenital polycythemia with paraganglioma. J Mol Med (Berl). 2013 Apr;91(4):507-12. http://dx.doi.org/10.1007/s00109-012-0967-z

70. Yang C, Hong CS, Prchal JT, Balint MT, Pacak K, Zhuang Z. Somatic mosaicism of EPAS1 mutations in the syndrome of paraganglioma and somatostatinoma associated with polycythemia. Hum Genome Var. 2015 Dec;2:15053. http://dx.doi.org/10.1038/hgv.2015.53

71. Ladroue C, Carcenac R, Leporrier M, Gad S, Le Hello C, Galateau-Salle F, et al. PHD2 mutation and congenital erythrocytosis with paraganglioma. N Engl J Med. 2008 Dec;359(25):2685-92. http:// dx.doi.org/10.1056/NEJMoa0806277

72. Burnichon N, Rohmer V, Amar L, Herman P, Leboulleux S, Darrouzet V, et al. The succinate dehydrogenase genetic testing in a large prospective series of patients with paragangliomas. J Clin Endocrinol Metab. 2009 Aug;94(8):2817-27. http://dx.doi.org/10.1210/jc.2008-2504

73. Benn DE, Robinson BG, Clifton-Bligh RJ. 15 years of paraganglioma: Clinical manifestations of paraganglioma syndromes types 1-5. Endocr Relat Cancer. 2015 Aug;22(4):T91-103. http://dx.doi. org/10.1530/ERC-15-0268

74. Pamporaki C, Hamplova B, Peitzsch M, Prejbisz A, Beuschlein F, Timmers HJLM, et al. Characteristics of pediatric vs adult pheochromocytomas and paragangliomas. J Clin Endocrinol Metab. 2017 Apr;102(4):1122-32. http://dx.doi.org/10.1210/jc.2016-3829

75. Gill AJ, Hes O, Papathomas T, Šedivcová M, Tan PH, Agaimy A, et al. Succinate dehydrogenase (SDH)-deficient renal carcinoma: A morphologically distinct entity: A clinicopathologic series 
of 36 tumors from 27 patients. Am J Surg Pathol. 2014 Dec;38(12):1588-602. http://dx.doi. org/10.1097/PAS.0000000000000292

76. Xekouki P, Stratakis CA. Succinate dehydrogenase (SDHx) mutations in pituitary tumors: Could this be a new role for mitochondrial complex II and/or Krebs cycled effects? Endocr Relat Cancer. 2012 Oct;19(6):C33-40. http://dx.doi.org/10.1530/ERC-12-0118

77. Dénes J, Swords F, Rattenberry E, Stals K, Owens M, Cranston T, et al. Heterogeneous genetic background of the association of pheochromocytoma/paraganglioma and pituitary adenoma: Results from a large patient cohort. J Clin Endocrinol Metab. 2015 Mar;100;3:E531-41. http://dx.doi.org/10.1210/ jc. 2014-3399

78. Killian JK, Miettinen M, Walker RL, Wang Y, Zhu YJ, Waterfall JJ, et al. Recurrent epimutation of SDHC in gastrointestinal stromal tumors. Sci Transl Med. 2014 Dec;6(268):268ral77. http://dx.doi. org/10.1126/scitranslmed.3009961

79. Janeway KA, Kim SY, Lodish M, Nosé V, Rustin P, Gaal J, et al. Defectsin succinate dehydrogenase in gastrointestinal stromal tumors lacking KIT and PDGFRA mutations. Proc Natl Acad Sci U S A. 2011 Jan;108(1): 314-18.

80. Pasini B, McWhinney SR, Bei T, Matyakhina L, Stergiopoulos S, Muchow M, et al. Clinical and molecular genetics of patients with the Carney-Stratakis syndrome and germline mutations of the genes coding for the succinate dehydrogenase subunits SDHB, SDHC, and SDHD. EurJ Hum Genet. 2008 Jan;16(1):79-88. http://dx.doi.org/10.1038/sj.ejhg.5201904

81. Hensen EF, Jordanova ES, van Minderhout IJHM, Hogendoorn PC, Taschner PE, van der Mey AG, et al. Somatic loss of maternal chromosome 11 causes parent-of-origin-dependent inheritance in SDHD-linked paraganglioma and pheochromocytoma families. Oncogene. 2004 May;20(23): 4076-83. http://dx.doi.org/10.1038/sj.onc.1207591

82. Hoekstra AS, Hensen EF, Jordanova ES, Korpershoek E, van der Horst-Schrivers AN, Cornelisse C, et al. Loss of maternal chromosome 11 is a signature event in SDHAF2, SDHD, and VHLrelated paragangliomas, but less significant in SDHB-related paragangliomas. Oncotarget. 2017 Feb;8(9):14525-36. http://dx.doi.org/10.18632/oncotarget.14649

83. Burnichon N, Mazella JM, Drui D, Amar L, Bertherat J, Coupier I, et al. Risk assessment of maternally inherited SDHD paraganglioma and phaeochromocytoma. J Med Genet. 2017 Feb;54(2):125-33. http://dx.doi.org/10.1136/jmedgenet-2016-104297

84. Niemann S, Müller U. Mutations in SDHC cause autosomal dominant paraganglioma, type 3. Nat Genet. 2000 Nov;26(3):268-70. http://dx.doi.org/10.1038/81551

85. Schiavi F, Boedeker CC, Bausch B, Peçzkowska M, Gomez CF, Strassburg T, et al. Predictors and prevalence of paraganglioma syndrome associated with mutations of the SDHC gene. JAMA. 2005 Oct 26;294(16):2057-63. http://dx.doi.org/10.1001/jama.294.16.2057

86. Bennedbæk M, Rossing M, Rasmussen ÅK, Gerdes AM, Skytte AB, Jensen UB, et al. Identification of eight novel SDHB, SDHC, SDHD germline variants in Danish pheochromocytoma/paraganglioma patients. Hered Cancer Clin Pract. 2016 Jun 8;14:13. http://dx.doi.org/10.1186/s13053-016-0053-6

87. Hao HX, Khalimonchuk O, Schraders M, Dephoure N, Bayley JP, Kunst H, et al. SDH5, a gene required for flavination of succinate dehydrogenase, is mutated in paraganglioma. Science. 2009 Aug;325(5944):1139-42. http://dx.doi.org/10.1126/science.1175689

88. van Baars F, Cremers C, van den Broek P, Geerts S, Veldman J. Genetic aspects of nonchromaffin paraganglioma. Hum Genet. 1982;60(4):305-9. http://dx.doi.org/10.1007/BF00569208

89. Bayley JP, Kunst HP, Cascon A, Sampietro ML, Gaal J, Korpershoek E, et al. SDHAF2 mutations in familial and sporadic paraganglioma and phaeochromocytoma. Lancet Oncol. 2010 Apr;11(4): 366-72. http://dx.doi.org/10.1016/S1470-2045(10)70007-3

90. Bausch B, Schiavi F, Ni Y, Welander J, Patocs A, Ngeow J, et al. Clinical characterization of the pheochromocytoma and paraganglioma susceptibility genes SDHA, TMEM127, MAX, and SDHAF2 for gene-informed prevention. JAMA Oncol. 2017 Sep;3(9):1204-12. http://dx.doi.org/10.1001/ jamaoncol.2017.0223

91. Clark GR, Sciacovelli M, Gaude E, Walsh DM, Kirby G, Simpson MA, et al. Germline FH mutations presenting with pheochromocytoma. J Clin Endocrinol Metab. 2014 Oct;99(10):E2046-50. http:// dx.doi.org/10.1210/jc.2014-1659 
92. Muller M, Ferlicot S, Guillaud-Bataille M, Le Teuff G, Genestie C, Deveaux S. Reassessing the clinical spectrum associated with hereditary leiomyomatosis and renal cell carcinoma syndrome in French FH mutation carriers. Clin Genet. 2017 Dec;92(6):606-15. http://dx.doi.org/10.1111/cge.13014

93. Udager AM, Magers MJ, Goerke DM, Vinco ML, Siddiqui J, Cao X, et al. The utility of SDHB and FH immunohistochemistry in patients evaluated for hereditary paraganglioma-pheochromocytoma syndromes. Hum Pathol. 2018 Jan;71:47-4. http://dx.doi.org/10.1016/j.humpath.2017.10.013

94. Aufforth RD, Ramakant P, Sadowski SM, Mehta A, Trebska-McGowan K, Nilubol N, et al. Pheochromocytoma screening initiation and frequency in von Hippel-Lindau syndrome. J Clin Endocrinol Metab. 2015 Dec;100(12):4498-504. http://dx.doi.org/10.1210/jc.2015-3045

95. Walther MM, Reiter R, Keiser HR, Choyke PL, Venzon D, Hurley K, et al. Clinical and genetic characterization of pheochromocytoma in von Hippel-Lindau families: Comparison with sporadic pheochromocytoma gives insight into natural history of pheochromocytoma. J Urol. 1999 Sep;162(3 Pt 1):659-64. http://dx.doi.org/10.1097/00005392-199909010-00004

96. Comino-Méndez I, Gracia-Aznárez FJ, Schiavi F, Landa I, Leandro-García LJ, Letón R, et al. Exome sequencing identifies MAX mutations as a cause of hereditary pheochromocytoma. Nat Genet. 2011 Jun 19;43(7):663-7. http://dx.doi.org/10.1038/ng.861

97. Ayala-Ramirez M, Feng L, Johnson MM, Ejaz S, Habra MA, Rich T, et al. Clinical risk factors for malignancy and overall survival in patients with pheochromocytomas and sympathetic paragangliomas: Primary tumor size and primary tumor location as prognostic indicators. J Clin Endocrinol Metab. 2011 Mar;96(3):717-25.

98. King KS, Prodanov T, Kantorovich V, Fojo T, Hewitt JK, Zacharin M, et al. Metastatic pheochromocytoma/paraganglioma related to primary tumor development in childhood or adolescence: Significant link to SDHB mutations. J Clin Oncol. 2011 Nov;29(31):4137-42. http://dx.doi.org/10.1210/ jc. 2010-1946

99. Bausch B, Borozdin W, Neumann HP, European-American Pheochromocytoma Study G. Clinical and genetic characteristics of patients with neurofibromatosis type 1 and pheochromocytoma. N Engl J Med. 2006 Jun;354(25):2729-31. http://dx.doi.org/10.1056/NEJMc066006

100. Bausch B, Borozdin W, Mautner VF, Hoffmann MM, Boehm D, Robledo M, et al. Germline NF1 mutational spectra and loss-of-heterozygosity analyses in patients with pheochromocytoma and neurofibromatosis type 1. J Clin Endocrinol Metab. 2007 Jul;92(7):2784-92. http://dx.doi.org/10.1210/ jc. $2006-2833$

101. Janssen I., Blanchet EM, Adams K, et al. Superiority of [68Ga]-DOTATATE PET/CT to other functional imaging modalities in the localization of SDHB associated metastatic pheochromocytoma and paraganglioma. Clin Cancer Res. 2015 Sep;21(17):3888-95. http://dx.doi.org/10.1158/1078-0432. CCR-14-2751

102. Yao L, Schiavi F, Cascon A, Qin Y, Inglada-Pérez L, King EE, et al. Spectrum and prevalence of FP/TMEM127 gene mutations in pheochromocytomas and paragangliomas. JAMA. 2010 Dec;304(23):2611-19. http://dx.doi.org/10.1001/jama.2010.1830

103. Abermil N, Guillaud-Bataille M, Burnichon N, Venisse A, Manivet P, Guignat L, et al. TMEM127 screening in a large cohort of patients with pheochromocytoma and/or paraganglioma. J Clin Endocrinol Metab. 2012 May;97(5):E805-9. http://dx.doi.org/10.1210/jc.2011-3360

104. Quayle FJ, Fialkowski EA, Benveniste R, Moley JF. Pheochromocytoma penetrance varies by RET mutation in MEN 2A. Surgery. 2007 Dec;142(6):800-5. http://dx.doi.org/10.1016/j.surg.2007.09.013

105. Rodriguez JM, Balsalobre M, Ponce JL, Ríos A, Torregrosa NM, Tebar J, et al. Pheochromocytoma in MEN 2A syndrome. Study of 54 patients. World J Surg. 2008 Nov;32(11):2520-6. http://dx.doi. org/10.1007/s00268-008-9734-2

106. Welander J, Andreasson A, Juhlin CC, Wiseman RW, Bäckdahl M, Höög A, et al. Rare germline mutations identified by targeted next-generation sequencing of susceptibility genes in pheochromocytoma and paraganglioma. J Clin Endocrinol Metab. 2014 Jul;99(7):E1352-60. http://dx.doi.org/10.1210/ jc. 2013-4375

107. Bausch B, Wellner U, Bausch D, Schiavi F, Barontini M, Sanso G, et al. Long-term prognosis of patients with pediatric pheochromocytoma. Endocr Relat Cancer. 2014 Dec;21(1):17-15. http://dx.doi. org/10.1530/ERC-13-0415 
108. Cascon A, Inglada-Perez L, Comino-Mendez I, de Cubas AA, Letón R, Mora J, et al. Genetics of pheochromocytoma and paraganglioma in Spanish pediatric patients. Endocr Relat Cancer. 2013 May;20(3):Ll-6. http://dx.doi.org/10.1530/ERC-12-0339

109. Babic B, Patel D, Aufforth R, Assadipour Y, Sadowski SM, Quezado M, et al. Pediatric patients with pheochromocytoma and paraganglioma should have routine preoperative genetic testing for common susceptibility genes in addition to imaging to detect extra-adrenal tumors. Surgery. 2017 Jan;161(1):220-7. http://dx.doi.org/10.1016/j.surg.2016.05.059

110. Richter S, Qin N, Pacak K, Eisenhofer G. Role of hypoxia and HIF2 $\alpha$ in development of the sympathoadrenal cell lineage and chromaffin cell tumors with distinct catecholamine phenotypic features. Adv Pharmacol. 2013;68:285-317. http://dx.doi.org/10.1016/B978-0-12-411512-5.00014-2

111. van Nederveen FH, Gaal J, Favier J, Korpershoek E, Oldenburg RA, de Bruyn EM, et al. An immunohistochemical procedure to detect patients with paraganglioma and phaeochromocytoma with germline SDHB, SDHC, or SDHD gene mutations: A retrospective and prospective analysis. Lancet Oncol. 2009 Aug;10(8):764-71. http://dx.doi.org/10.1016/S1470-2045(09)70164-0

112. Santi R, Rapizzi E, Canu L, Ercolino T, Baroni G, Fucci R, et al. Potential pitfalls of SDH immunohistochemical detection in paragangliomas and phaeochromocytomas harbouring germline SDHx gene mutation. Anticancer Res. 2017 Feb;37(2):805-12. http://dx.doi.org/10.21873/anticanres.11381

113. Menara M, Oudijk L, Badoual C, Bertherat J, Lepoutre-Lussey C, Amar L, et al. SDHD immunohistochemistry: A new tool to validate SDHx mutations in pheochromocytoma/paraganglioma. J Clin Endocrinol Metab. 2015 Feb;100(2):E287-91. http://dx.doi.org/10.1210/jc.2014-1870

114. Martucci VL, Pacak K. Pheochromocytoma and paraganglioma: Diagnosis, genetics, management, and treatment. Curr Probl Cancer. 2014 Jan-Feb;38(1):7-41. http://dx.doi.org/10.1016/j. currproblcancer.2014.01.001

115. Toledo RA, Dahia PLM. Next-generation sequencing for the diagnosis of hereditary pheochromocytoma and paraganglioma syndromes. Curr Opin Endocrinol Diabetes Obes. 2015 Jun;22(3):169-79. http://dx.doi.org/10.1097/MED.0000000000000150

116. Maher E. Phaeochromocytoma and paraganglioma: Next-generation sequencing and evolving Mendelian syndromes. Clin Med (Lond). 2014 Aug;14(4):440-4. http://dx.doi.org/10.7861/ clinmedicine. 14-4-440

117. Crone J, Verdudo AD, Grandberg D, Welin S, Stålberg P, Hellman P, et al. Next-generation sequencing in the clinical genetic screening of patients with pheochromocytoma and paraganglioma. Endocr Connect. 2013 May;28(2):104-11. http://dx.doi.org/10.1530/EC-13-0009

118. Toledo RA, Dahia PLM. Next-generation sequencing for the genetic screening of phaeochromcytomas and paragangliomas: Riding the new wave, but with caution. Clin Endocrinol (Oxf). 2014 Jan;80(1):23-4. http://dx.doi.org/10.1111/cen.12357

119. Rattenberry E, Vialard L, Yeung A, Bair H, McKay K, Jafri M, et al. A comprehensive next generation sequencing-based genetic testing strategy to improve diagnosis of inherited pheochromocytoma and paraganglioma. J Clin Endocrinol Metab. 2013 Jul;98(7):E1248-56. http://dx.doi.org/10.1210/ jc. 2013-1319 